

Shirkah

Journal of Economics and Business 
Shirkah: Journal of Economics and Business

Volume 5, No. 3, September-December 2020

ISSN: 2503-4235 (p); 2503-4243 (e)

\section{Table of Contents}

Institutional Quality and Sukuk Development: A Study of Five 286 OIC Countries

Nuhbatul Basyariah, Hadri Kusuma, Ibnu Qizam

Performance of GoFood MSEs Partnership: An Integration of

Entrepreneurial Orientation, Marketing Capabilities, and

Brand Orientation

Septi Kurnia Prastiwi, Asep Maulana Rohimat

Islamic Social Reporting Disclosure of Sharia Commercial

Banks in Indonesia: A Form of Social Responsibility

Riduwan, Lu'liyatul Mutmainah, Rofiul Wahyudi

Concentration and Specialization of Economic Activities in the 362

Kingdom of Saudi Arabia

Salim Bourchid Abdelkader, Hamidouche M'hamed, Abderrazak

Ahmed Zian

Indonesian Islamic Commercial Banks' Efficiency: A Stochastic 386 Frontier Analysis

Sylva Alif Rusmita, Devy Ariesta Putri

Islamic Economics Development in Indonesia: Reflection on

Contemporary Thoughts of Muslim Intellectuals

Zainal Abidin 


\title{
Institutional Quality and Sukuk Development: A Study of Five OIC Countries
}

\author{
Nuhbatul Basyariah* \\ Department of Sharia Banking, STEI Hamfara Yogyakarta, Indonesia \\ Doctoral Program in Islamic Economics, UIN Sunan Kalijaga Yogyakarta, Indonesia \\ ${ }^{*}$ Corresponding author: nuhbah.hamfara@gmail.com \\ Hadri Kusuma \\ Faculty of Business and Economics, Universitas Islam Indonesia, Indonesia \\ hkusuma@uii.ac.id \\ Ibnu Qizam \\ Faculty of Economics and Business, UIN Syarif Hidayatullah Jakarta, Indonesia \\ qzami68@gmail.com
}

\begin{abstract}
The objective of this study is to shed some light on the effect of institutional quality on the development of the global sukuk market. Specifically, this study examines the impacts of the institutional quality that adopts three dimensions of the Worldwide Governance Indicators (WGI), i.e., Rule of Law (RL), Regulatory Quality (RQ), and Government effectiveness (GE) on the global sukuk development of the top-five countries of sukuk issuance, i.e., Malaysia, Kingdom of Saudi Arabia, United Arab Emirates, Indonesia, and Bahrain. Drawing on a quantitative study with the data in the forms of global sukuk issuance from 2002 to 2017, panel-data regression (OLS) and General Method of Moment (GMM) were applied. This study showed that RL and GE have a significantly positive effect on sukuk issuance; however, RQ did not influence the development of the global sukuk market. These results imply that a country that is capable to maintain the institutional quality, especially in terms of rule of law and government effectiveness, will most likely be the country that can successfully develop the sukuk market. These results play a crucial role in filling a research gap among previous studies and provide an empirical evidence of the government's role and its influence on the sukuk development.
\end{abstract}

Keywords: Institutional Quality; Islamic Financial Development; Sukuk Development; Worldwide Governance Indicators 


\section{Introduction}

Nowadays, sukuk instruments are an important part of the Islamic financial market. The sukuk market represents the secondlargest component of the Islamic financial industry after Islamic banking. Since the 2000s, sukuk has the potential to become an Islamic financial instrument for meeting the needs of the state and corporate funds (Kusuma \& Silva, 2014), and is an attractive investment choice for investors in Muslim-majority and non-Muslim countries (Hassan et al., 2019; Abd. Aziz et al., 2016). The sukuk market provides alternative funding and a base for broader investors for corporate and state entities (Ahmad et al., 2012). Currently, sukuk is also included in the sub-sector which plays an important role in driving the economy of a country in the world.

The International Islamic Financial Market (IIFM) reports the development of sukuk since it was first published and registered in the global market with a value of USD 66,830 million in 2001, continuing to rise and growing to USD 137,599 Million in 2012, and USD 135,557 Million in 2013. Although it had dropped, however, it rose again and in 2018 stood at USD 123,150 Million (International Islamic Financial Market, 2018). The facts prove that sukuk is not only in demand by Muslims but also in demand by non-Muslims both individually and nationally. This fact is evidenced by the eight non-member countries of the Islamic cooperation organizations (OIC) that are currently participating in issuing sukuk in the global market, e.g., France, Germany, Luxembourg, Britain, Singapore, Hong Kong, South Africa, and the United States (Smaoui \& Ghouma, 2020).

Various types of sukuk are issued in the global sukuk market, i.e., sovereign sukuk (sukuk issued by the state), corporate sukuk (sukuk issued by the company), quasi-sovereign sukuk (sukuk issued by business entities/state institutions), and institutional financial sukuk (FIs-sukuk) (sukuk issued by financial service companies). International Islamic Financial Market (2018) has launched a report on the issuance 
of sukuk in the global market, i.e., state Sukuk amounts to USD 220,848 million (45\%), corporate sukuk (USD 135,380 million or 27,58\%), quasisovereign (USD 96,570 million or 19.68\%), and FIs (USD 37,985 million or $7.74 \%$ ). IIFM and Thomson Reuters have released data on the global market developments of sukuk showing the fact that certain countries have been highly prominent in sukuk issuances such as Malaysia, UAE, KSA, Bahrain, and Indonesia. These five countries have been the countries that occupy the top five of the world in sukuk issuance in 2017, namely Malaysia being the first country in the total outstanding sukuk, USD 168,942 Million, followed by Saudi Arabia (USD 52,546 Million), Indonesia (USD 36.986 Million), and UAE (USD 31,905) for the second, third, and fourth position in the global sukuk outstanding respectively. The character of sukuk is different from conventional financial instruments due to the necessity of underlying assets and its freeinterest rate attributes which makes it more stable and less volatile.

However, regardless of the seemingly better attributes on sukuk, the great potential of Islamic finance is not maximal and is far from the market-share target. Apart from the significant growth rates experienced by the Islamic finance industry in several countries, over the past 20 years, the overall performance of this industry has been inadequate and unsatisfactory. The Islamic financial industry, including sukuk, is still very small; when compared to the conventional financial industry, it looks uncompetitive and, to some extent, becomes very vulnerable (BAPPENAS, 2016). The gap between sukuk prices compared to conventional bond prices continues to narrow and, in some cases, sukuk are getting tighter but markets continue to keep their risk-aversion strategy intact (International Islamic Financial Market, 2014). Various problems that emerge in the Islamic financial industry in Indonesia include, for example, many gaps in the sharia governance framework that exacerbate operational complexity, delays, and increased costs in some cases (BAPPENAS, 2016).

A variety of problems that hamper the pace of development of Islamic finance require the role of the government in solving them, to 
form an investment climate that supports the development of the Islamic finance industry. (Asian Development Bank, 2005) states that among the factors that affect the investment climate is the role of government and securities companies/issuers, called the institutional role. Robinson (1952) explicitly states that institutions are the most important source that determines whether or not the economy of a country gets in failure or progress. Countries whose governance have established or whose economic institutions have been inclusive tend to have good economic performance since its institutional presence is not to negate the market mechanism, but to ensure that the market runs in line with the luminous rules, thereby all economic actors get equal access and certainty in doing business (Yustika, 2012).

Institutional quality is a set of rules and constraints that shape economic behavior and incentives. Experts argue that institutional quality is the main determinant of economic development (Challe et al., 2019). Some research states that institutional quality has an impact on investment development (Wang et al., 2014). Other evidence suggests that a better institutional environment can stimulate $R \& D$ activities by providing collaborative capacity building to companies (Wang et al., 2014; Intapan \& Sriboonchitta, 2019). Other empirical evidence shows a strongly significant institutional quality effect on economic and financial development (Fagbemi \& Ajibike, 2018; Khan et al., 2019) on the conventionally-financial development (Phuc et al., 2019), as well as on the Islamic finance development (Smaoui \& Khawaja, 2017). Of course, this has become an important basis for further inquiry related to the degree to which the institutional quality has an impact on sukuk instruments.

Given the empirical studies and existing recommendations, it is important to examine the degree to which the role of the government has an impact on the development of Islamic finance, especially the development of global sukuk. Interestingly, due to very limited empirical studies regarding the institutional quality in Islamic finance, especially sukuk, this study aims to analyze the effect of institutional 
quality (using three of the six WGI indicators, such as Rule of Law (RL), Regulatory Quality (RQ), and Government effectiveness) on sukuk development. It is worth exploring and examining due to the problems and constraints faced by Islamic finance, especially sukuk, such as legal regulations. Additionally, it will also provide an empirical novelty regarding the impact of institutional quality, i.e., Rule of Law (RL), Regulatory Quality (RQ), and Government effectiveness, on sukuk development.

\section{Review of Literature}

Sukuk is another term of Islamic bonds, and it has been known in Islam since the Middle Ages, where Muslims used the instrument in the context of international trade. Sukuk is a plural form of the word 'sakk' which means a certificate or note. Auditing and Accounting Organization of Islamic Financial Institutions (AAOIFI) defines sukuk as proportional representation of ownership of assets for a certain period with risks and rewards associated with cash flow through underlying assets in the hands of investors (Paltrinieri et al., 2018). Based on the contract, sukuk is divided into sukuk al-ijara, sukuk alwakala, sukuk al-mudaraba, sukuk al-musharaka, sukuk al-istithmar, sukuk al-manafa'a, sukuk al-istisna'a, and sukuk al-murabaha. The various types of sukuk are described by Smaoui and Ghouma (2020) and Borhan and Ahmad (2018). Sukuk is a sharia capital-market instrument as well as sharia financial-trading instruments; therefore, it requires a right product criteria and arrangements in the development process to its full potential (Hadiah, 2016), and does not leave out its shariaprinciples. Thus, public are going to welcome sukuk with a full confidence and trust.

Various measurement models are applied as institutional indicators. The World Bank determines the measurement of the country's governance index or state institutions using the six governance dimensions included in the Worldwide Governance Indicators (WGI) by Kaufmann et al. (2009) i.e., Voice and 
Accountability (VA), Political Stability and Absence of Violence (PSAV), Governance Effectiveness (GE), Regulatory Quality (RQ), Rule of Law (RL), and Control of Corruption (CC). Studies on the role of institutional quality have begun and have been applied as an indicator to measure economic and financial development spearheaded by Law and Azman-Saini (2012). They confirms that there has been no previous research conducted using a governance index to measure institutional quality and its role in financial development. Since then, research has been emerging to apply the same measuring index to represent the institutional quality effect on economic development in general.

Among them are the studies that examine institutional frameworks for economic growth. The result shows that a stable institutional framework will drive economic growth, while weak institutional activity causes stagnant economic growth (Jain et al., 2017). Buchanan et al. (2012), in their study of institutional quality with FDI-flow, conclude that institutional quality strongly influences FDIflow; thus, the institutional quality significantly provides positive impact on FDI (Febrina \& Sumiyarni, 2014). The study is statistically not much different from Globerman and Shapiro (2002) who examine institutions with their foreign investment. The result portrays that institutions have a positive relationship with foreign direct investment. A research using many institutional quality measures as conducted by Gani (2007) finds out that the Rule of Law (RL), Regulatory Quality (RQ), Control of Corruption (CC), and Political Stability and Absence of Violence (PSAV) have positive impacts on the flow of FDI. Moreover, research on the political stability effect on financial development is also strengthened by Roe and Siegel (2011) who explains the same results that political stability significantly affects financial development.

The potential connection between institutional quality and financial development has been reviewed by Khan et al. (2019) in their research on financial developments in the United States who conclude that institutional quality has a significantly positive effect on financial 
development in the US. While their research uses conventional financial data objects, it is interesting to conduct a more in-depth study on the relationship between institutional quality and Islamic finance. Huang (2010) finds out a positive institutional-improvement effect on financial development at least in the short term, especially for lowincome, developing, and economically-fragmented countries. Khan et al. (2019) recommend to include institutional-quality considerations in policymaking, specifically for financial development.

Other institutional research results examining the relation of institutional quality to RQ and PSAV indicators show a positive impact of institutional quality on investment development (Alam \& Yazdifar, 2019). The relationship between institutional quality and the economy and finance, in general, depicts a stable institutional framework in driving an economic growth, while weak institutional activity leads an economic growth to stagnate (Jain et al., 2017). Ojeka et al. (2019) also confirm that weak institutional quality would reduce the market in the case of Nigeria. The study is also based on previous research conducted by Law et al. (2012) who examine the relationship of institutional quality with a country's finance. The result reveals that high-quality institutions are very important in explaining the financial development of a market. In addition to institutional quality using aggregate data, Ojeka et al. (2019) also test institutional quality by adopting individual indicators, i.e., PSAV, GE, RL, VA, and the result indicate a positive correlation to financial markets and corporate accounting performance. These results support the statement that institutional factors play an important role in economic and financial development and put pressure on policymakers to develop stable reforms to encounter uncertainty (Cherif \& Gazdar, 2010). Consequently, it is proven that institutional quality has a positive and significant effect on financial development of a country (Tran, 2018; Khan et al., 2019; Alam \& Yazdifar, 2019).

Although a number of previous studies have used institutional quality as a variable often involved in finance studies, an empirical 
correlation between institutional quality and Islamic financial instruments, specifically sukuk, still remains more paucity of evidence. Initially, an empirical study on institutional quality and sukuk development was conducted by Said and Grassa (2013) who discussed the determinants of the development of the sukuk market applying various independent variables, inter alia, the RQ indicator for institutional quality. The results suggest that the Regulatory Quality (RQ) significantly influences the development of the sukuk market. The implication is that the countries with high institutional quality in terms of RQ will have a huge sukuk market, due to the efficiency and reliability in regulatory and law enforcement.

A study on the determinants of the sukuk market development was also conducted by Smaoui and Khawaja (2017) by applying some variables to proxy a combination of structural, financial, and institutional factors. The study suggests significant effects on the variables discussed. It should be noted that the greater the economy of a country is and the more Muslim population is, the better the investment profile of a country will be. The lower the corruption of a country is, the more the sukuk market of a country will be. Institutional quality has proven to be a factor that has a strong influence on sukuk development, as supported by Said and Grassa (2013). They contend that the institutional quality proxied by RL and RQ has a positive and significant impact on sukuk development. While Said and Grassa (2013) test several types of variables that might affect sukuk development from macroeconomic indicators and institutional quality, the in-hand study is specifically focused on examining the institutional quality on sukuk development to avoid the bias coming from the government-role variables and their influence on the sukuk development as studied by Said and Grassa (2013). Given the above description, it is hypothesized that:

H1: Rule of Law has a positive effect on the development of the global sukuk market. 
H2: Regulatory Quality has a positive effect on the development of the global sukuk market.

H3: Government Effectiveness has a positive effect on the development of the global sukuk market.

\section{Research Method}

\section{Sample Selection and Data Sources}

The present study aimed to examine the potential correlation between several dimensions of WGI-World Bank on the development of global sukuk market in five OIC countries. To this end, this study made use of secondary data in the forms of global-sukuk-issuance released by countries being in the highest positions in sukuk issuance, i.e. Malaysia, KSA, UAE, Indonesia, and Bahrain. These countries are also listed in International Islamic Financial Market (IIFM) as a proxy for the development of the global sukuk market. As for the institutional quality data, this study adopted Worldwide Governance Indicators (WGI) established by the World Bank (Kaufmann et al., 2011). The data were sourced from the annual sukuk issuance and institutional quality from 2002-2017.

\section{Variable Measurements}

This study is quantitatively directed to investigate the effect of independent variable, that is institutional quality proxied by three of the six WGI-World Bank dimensions of governance, i.e. Rule of Law (RL), Regulatory Quality (RQ), and Government Effectiveness (GE) on the global sukuk development. In determining the three of the six WGI dimensions, this study took into account insights from Langbein and Knack (2012) and Phuc et al. (2019), who posit that institutional-quality indicators can be operated individually (see table 1). In a similar direction, Phuc et al. (2019) further argue that some of the dimensions partially affects a sukuk development. Hence, this study pointed out how RL, RQ, and GE as part of WGI-World Bank dimensions 
potentially provide an impact on the global sukuk development in the five OIC countries.

Table 1: Definition of Operational Variables

\begin{tabular}{|c|c|c|c|}
\hline \multicolumn{2}{|c|}{ Variable Definition } & Unit & Source \\
\hline \multicolumn{4}{|c|}{ Dependent Variable } \\
\hline $\begin{array}{l}\text { Sukuk } \\
\text { Issuance (SI) }\end{array}$ & $\begin{array}{l}\text { Sukuk data available in the global } \\
\text { market is a combination of the } \\
\text { three types of sukuk from the issuer } \\
\text { side: state sukuk, corporate sukuk, } \\
\text { quasi sukuk, and FIS (Financial } \\
\text { Institutional sukuk or sukuk issued } \\
\text { by financial institutions) }\end{array}$ & $\begin{array}{l}\text { USD } \\
\mathrm{M} \%\end{array}$ & IIFM \\
\hline \multicolumn{4}{|c|}{ Independent Variables } \\
\hline $\begin{array}{l}\text { Rule of Law } \\
\text { (RL) }\end{array}$ & $\begin{array}{l}\text { Illustrates perceptions of the degree } \\
\text { to which agents have confidence in } \\
\text { and abide by the rules of society, } \\
\text { and, in particular, the contract- } \\
\text { enforcement quality, property } \\
\text { rights, the police, and the courts, as } \\
\text { well as the likelihood of crime and } \\
\text { violence. }\end{array}$ & $\%$ & WGI-WB \\
\hline $\begin{array}{l}\text { Regulatory } \\
\text { Quality (RQ) }\end{array}$ & $\begin{array}{l}\text { Illustrates perceptions of the ability } \\
\text { of the government to formulate and } \\
\text { implement sound policies and } \\
\text { regulations that permit and } \\
\text { promote private sector } \\
\text { development. }\end{array}$ & $\%$ & WGI-WB \\
\hline $\begin{array}{l}\text { Government } \\
\text { Effectiveness } \\
(\mathrm{GE})\end{array}$ & $\begin{array}{l}\text { Illustrates perceptions of the } \\
\text { public-services quality, the civil- } \\
\text { service quality and the degree of its } \\
\text { independence from political } \\
\text { pressures, the policy-formulation, } \\
\text { and implementation quality, and } \\
\text { the credibility of the government's } \\
\text { commitment to such policies. }\end{array}$ & $\%$ & WGI-WB \\
\hline
\end{tabular}

Source: Langbein and Knack (2012) and Phuc et al. (2019)

Vol. 5 No. 3, September - December 2020 
The data were processed using Panel Data Regression and Generalized Method of Moment (GMM) Regression. GMM is an expanded version of the moment method to estimate parameters. The moment method cannot be used if the number of instrumental variables is greater than the number of parameters to be estimated. GMM equates the condition moment of the population with the condition moment of the sample. GMM method is one method that can overcome data conditions by violating assumptions in regression analysis. GMM is obtained by minimizing the number of squares weighted from the moment of sample conditions (Ekananda, 2016). The regression model in this study is stated as follows:

$S I_{i t}=\beta_{0}+\beta_{1} R L_{i t}+\beta_{2} R Q_{i t}+\beta_{3} G E_{i t}+e$

where,

$S I_{i t}=S u k u k$ development proxied by sukuk issuance for country $i$, period $t$

$\beta_{0} \quad=$ Constant parameters

$\beta_{1}, \beta_{2}, \beta_{3}=$ Coefficients for $R L_{i t}, R Q_{i t}$, and $G E_{i t}$

$R L_{i t} \quad=$ Rule of Law for country $i$, period $t$;

$R Q_{i t} \quad=$ Regulatory Quality for country $i$, period $t$;

$G E_{i t}=$ Government Effectiveness for country $i$, period $t$;

e $\quad=$ Error terms.

There are at least two reasons that underlie the use of GMM approach. First, GMM is a common estimator and provides a useful framework for comparison and assessment. Second, GMM provides a simple alternative to other estimators, especially towards maximum likelihood. In order to assume the dynamic panel data, static panel models such as Pooled Least Square (PLS), Fixed-Effect (FEM), and Random-Effect Models (REM) presumably indicate bias and inconsistent estimators due to the existence of a correlation between the lag in the dependent variable $\left(S I_{i, t-1}\right)$ and the error terms $\left(e_{i t}\right)$. To deal with these problems, GMM was applied since it solved these problems by first-differencing the dynamic panel model to ensure that changes 
of $S I_{i, t-1}$ and $e_{i t}$ were uncorrelated. Roodman (2009) suggests that the coefficient value of $S I_{i, t-1}$ in the GMM model should be between PLS and FEM or PLS $\leq \mathrm{GMM} \leq \mathrm{FEM}$.

\section{Results}

Data analysis commenced with data smoothing, by converting the monetary unit from the local currency into USD, then changed into a natural-logarithm $(\ln )$ model. Smoothing the data was run since the variables between sukuk issuance and institutional quality indicators were measured in different units, the monetary units (million USD) for sukuk issuance, and the percentage units for institutional quality indicators. Data smoothing was administered by changing the sukuk data into a natural-logarithm model; the sukuk units were changed from million USD into a percentage.

Table 2. Descriptive Statistics

\begin{tabular}{lcccc}
\hline & SI & RQ & RL & GE \\
\hline Mean & 12868.19 & 62.05093 & 57.62756 & 65.97137 \\
Median & 2251.000 & 66.90861 & 62.52962 & 68.33148 \\
Maximum & 97080.00 & 83.16327 & 78.36539 & 91.34615 \\
Minimum & 19.00000 & 20.91837 & 19.80198 & 38.23529 \\
Std. Dev. & 21450.04 & 14.35865 & 14.24026 & 15.32477 \\
Observations & 80 & 80 & 80 & 80 \\
\hline
\end{tabular}

The panel-data regression requires a classic assumption test and a choice between the common-effect (CEM), the fixed-effect (FEM), and the random-effect model (REM). Given table 3, the data has also satisfied all the classic assumption tests. Jargue-bera is more than 0.8 or 0.92; and Breuch-Pagan-Godfrey test for heteroscedasticity shows that $p$-value (ChiSquare $=0.73$ ) is greater than 0.05 , meaning that the data does not contain heteroscedasticity or homoscedasticity. Other evidence from the results of the multicollinearity test is illustrated in Table 4.

Table 3 shows that the data indicate multicollinearity, but since it is stated by Widarjono (2007: 103-104) that the BLUE estimator does not 
require assumptions to be free from multicollinearity problems, the model is continued. Following the autocorrelation test using the serial correlation LM-test, the result depicts that the probability value of ChiSquare (0.509) is greater than $\alpha=0.05$, meaning that we fail to reject $\mathrm{H} 0$, which further indicates that the model does not contain autocorrelation. Henceforth, the panel-data regression requires a model-selection test between CEM, FEM, and REM. The results are presented in table 5 .

Tabel 3: Heteroskedasticity Test: Breusch-Pagan-Godfrey

\begin{tabular}{llll}
\hline F-statistic & 0.349218 & Prob.F(3,12) & 0.7905 \\
Obs*R-squared & 1.284711 & Prob.Chi-Square(3) & 0.7328 \\
\hline
\end{tabular}

Table 4. Correlations

\begin{tabular}{cccc}
\hline & RL & RQ & GE \\
\hline RL & 1 & & \\
RQ & 0.937 & 1 & \\
GE & 0.818 & 0.843 & 1 \\
\hline
\end{tabular}

Table 5. Hypotheses Testing: CEM, FEM, and REM

Dependent variable: Sukuk Issuance (SI)

\begin{tabular}{llllllllll}
\hline Variable & \multicolumn{3}{c}{ CEM } & \multicolumn{3}{c}{ FEM } & \multicolumn{3}{c}{ REM } \\
\hline & koef & t-stat & Prob & Koef & t-stat & Prob & Koef & t-stat & Prob \\
C & 5,06 & 5,68 & $0,00^{* * *}$ & $-3,38$ & $-1,81$ & $0,07^{*}$ & 2,43 & 2,17 & $0,03^{* *}$ \\
RL & 0,10 & 2,57 & $0,01^{* * *}$ & 0,22 & 4,38 & $0,00^{* * *}$ & 0,12 & 3,12 & $0,00^{* * *}$ \\
RQ & $-0,06$ & $-1,67$ & $0,09^{*}$ & 0,01 & 0,18 & 0,85 & $-0,02$ & $-0,54$ & 0,59 \\
GE & 0,02 & 2,14 & $0,03^{* *}$ & $-0,04$ & $-2,52$ & $0,01^{* * *}$ & $-0,01$ & $-0,75$ & 0,45 \\
Adj. R ${ }^{2}$ & 0,25 & & & 0,57 & & & 0,19 & & \\
Chow-test & 0,00 & & & & & & & & \\
Hausman- & & & & 0,00 & & & & & \\
test & & & & & & & & & \\
\hline
\end{tabular}

Notes: Significant at level 10\%, ** Significant at level 5\%, ${ }^{* * * S i g n i f i c a n t ~ a t ~ l e v e l ~ 1 \% ~}$ 
Based on the table 5, the Chow-test results show that the FEM model is the best compared to CEM ( $p$-value=0,000), while the Hausman test shows that FEM is also the best model compared to REM ( $p$-value $=0,000)$. Hence, the model used in this research is FEM.

Referring to Verbeek (2012), the biased and inconsistent estimators in fixed-effect and random-effect models are still most likely to occur, due to, inter alia, endogeneity problems that should be eliminated. As a result, to get rid of these problems, a GMM test was applied, first, by looking at the validity of the model in the Sargan test using J-statistics (Ekananda, 2016). Sargan-statistic values distributed by chi-square statistic c (p-k) with the null hypothesis are validly overidentified. Calculating the $p$-value of Sargan statistical test by gauging the chi-square statistic $c(p-k)$, where $p=8$ is the rank instrument and $\mathrm{k}=4$ is the number of parameters, was conducted. Using an excel program, the $p$-value test shows that CHISQ.DIST.RT $(5.07,4)$ is 0.966 ; the value is more than 0.05 . If a p-value is more than 0.05 , valid overidentification applies.

Table 6. Hypotheses Testing using OLS and GMM models

Dependent Variable: Sukuk Issuance (SI)

\begin{tabular}{|c|c|c|c|c|c|c|}
\hline & \multicolumn{3}{|c|}{ OLS } & \multicolumn{3}{|c|}{ GMM } \\
\hline Variabel & Coef & t-stat & Prob & Coef & t-stat & Prob \\
\hline $\mathrm{C}$ & $-3,38$ & $-1,81$ & $0,07^{*}$ & $-3,377$ & $-1,812$ & $0,074^{*}$ \\
\hline RL & 0,14 & 2,54 & $0,013^{* * *}$ & 0,218 & 4,378 & $0,011^{* * *}$ \\
\hline $\mathrm{RQ}$ & 0,01 & 0,25 & 0,804 & 0,007 & 0,183 & 0,823 \\
\hline GE & 0,065 & 1,70 & $0,093^{*}$ & 0,065 & 1,99 & $0,049^{* * *}$ \\
\hline Adj. $R^{2}$ & 0,547 & & & & 0,547 & \\
\hline F-Statistics & \multicolumn{3}{|c|}{15,81} & \multicolumn{3}{|c|}{-} \\
\hline DW & \multicolumn{3}{|c|}{0,49} & \multicolumn{3}{|c|}{0,48} \\
\hline Inst. Rank & \multicolumn{3}{|c|}{ - } & \multicolumn{3}{|c|}{8} \\
\hline J-statistic & \multicolumn{3}{|c|}{-} & \multicolumn{3}{|c|}{5,07} \\
\hline Sargan test & \multicolumn{3}{|c|}{ - } & \multicolumn{3}{|c|}{0,966} \\
\hline
\end{tabular}

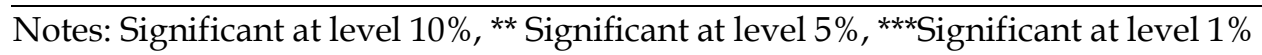


The results of Table 6 show that the three independent variables (RL, RQ, and GE) partially have a significantly positive impact on sukuk when the t-statistic values are greater than the corresponding critical tvalue of 2.776 with df: $n-k$, namely $8-4=4$. The relationship between the Rule of Law (RL) and sukuk, based on the results of the calculation, implies that the t-statistic value is 4.378 , higher than its critical $t$-value (2.776). Since $\mathrm{t}$ - statistic value $=4.378$ is greater than its critical $\mathrm{t}$-value (2.179) with a significance level of 0.0000 (less than $5 \%$ ), H1 is accepted, and $\mathrm{HO}$ is rejected, meaning that the Rule of Law (RL) partially has a significantly positive effect on sukuk development. The t-statistic value of 4.378 strengthens the above hypothesis and also proves that a significantly positive relationship between RL and the development of sukuk exists.

The relationship between Regulatory Quality (RQ) and sukuk development, based on the results of the calculation, suggests that the $\mathrm{t}$-statistic value is 0.183 , while its critical value is 2.776 ; so, the t-statistic value $(0.183)$ is less than its critical $t$-value (2.776) with a significance level of 0.855 , greater than $5 \%$. Hence, $\mathrm{H} 2$ is rejected and $\mathrm{H} 0$ is accepted, meaning that the Regulatory Quality has no positive effect on sukuk. Based on the $t$-stat. value, the RQ statistic shows that the RQ does not affect sukuk issuance.

The effect of Government Effectiveness (GE) on sukuk development is significant. Based on the results of the calculation, the $\mathrm{t}$-statistic value is 1.997; while its critical $\mathrm{t}$-value is 2.776 . The t-statistic value is 1.997 , less than its critical $t$-value (2.776) with a significance level of 0.049 , less than 0.05 . These results suggest that $\mathrm{H} 3$ is accepted and $\mathrm{H} 0$ is rejected, meaning that GE has a significant effect on sukuk development. The influence of GE on the sukuk development can be seen from the positive $t$-statistical value, indicating that the impact of GE on the sukuk development is positively significant, i.e., when GE increases, the sukuk market will also increases.

Referring to the results of hypotheses testing, it appears that the value of Adj. R Square is 0.567 . This means that the GMM model for the 
institutional quality variables of RL, RQ, and GE account for the sukuk variable by $56.7 \%$, while the rest $(43.3 \%)$ is explained by other variables not included in the model, such as macroeconomic variables, internal and external factors, and other instruments, i.e., both Islamic and conventional instruments. The coefficient of determination (0.567) is more than $50 \%$, suggesting that the institutional quality effect on sukuk development is relatively high. Furthermore, based on the above table, the regression equation can be seen as follows:

$\log S I=\beta_{0}+\beta_{1} R L+\beta_{2} R Q+\beta_{3} G E+e$

$\log S I=-3,377+0,218 R L+0,007 R Q+0,065 G E$

Given the abovementioned multiple-linear-regression equations, it can be seen that the constant ( $\alpha$ ) is $-3,377$. The constant is negative, meaning that if other variables ( $R L, R Q$, and GE) are kept to be constant or zero, the constant will be able to reduce the development of sukuk by $-3,377 \%$. The regression coefficient of $\mathrm{X} 1$ is 0.218 , showing a positive relationship, where every one-unit-of-percentage increase in RL will cause an increase in sukuk by $0.218 \%$. Conversely, if a decrease in RL by one unit will also cause a decrease in sukuk by 0.218 percent, assuming the other independent variables are constant.

Moreover, the regression coefficient of $\mathrm{RQ}$ is equal to 0.007 , meaning that the RQ coefficient of 0.007 shows a positive relationship where every one-unit-of-RQ increase will cause an increase in sukuk of 0.007 units. Conversely, if a decrease in RQ by one unit will also cause a decrease in sukuk by 0.007 units, assuming the other independent variables are constant. The regression coefficient of GE, amounting to 0.040, shows a negative relationship, where each one unit-of GE increase will cause a decrease in sukuk by 0.040 units. Conversely, if a decrease in GE by one unit will also cause an increase in sukuk by 0.040 units, assuming the other independent variables are constant. 


\section{Discussion}

The institutional quality of WGI is measured from a community survey of its government in dealing with related cases. The next impact is that it will affect the level of public confidence in deciding investment activities, both as an investor and an issuer. Several previous studies have concluded that the institutional quality, both aggregately and individually, has a significant effect on financial, investment and economic instruments (Alam \& Yazdifar, 2019; Jain et al., 2017; Choi et al., 2016; Huang, 2010; Gani, 2007). The development of most empirical studies on conventional finance has been still predominating the current debate of which its focus, object, and characteristics, of course, are different from Islamic finance, especially sukuk instruments (Paltrinieri et al., 2020).

This study finds empirical evidence that institutional quality also has a significant influence on the development of Islamic finance, especially sukuk in the global market, i.e. in the five OIC countries. The results of this study are mostly in accordance with the findings of Said and Grassa (2013) as well as Smaoui and Khawaja (2017) that the quality of individual institutions has a positive effect on sukuk, but different from theirs in some respects. In addition to applying different objects (countries) and the more-updated period of this study (20022017), the variables of interest in this study also focus on institutional quality to eliminate the macroeconomic-bias impact on the sukuk development as adopted in the study of Said and Grassa (2013). Meanwhile, Khawaja (2016) uses the ICRG (International Country Risk Guide) indicator as a measure of the institutional quality to affect sukuk instead of the WGI (Worldwide Governance Indicators pioneered by the World Bank) as applied in this study.

This study implies that when the sukuk development does not satisfy the expected market target, it is necessary to review the existing legal regulations, i.e. whether some possible obstacles for the sukuk development not realized by regulators exist. To identify these 
problems, it necessitates constructive suggestions, sourcing from, inter alia, research findings, and corrective actions from the stakeholders regarding the existing regulations. It is evident from the results of this study that the Rule of law has a significant and positive effect on the development of sukuk, implying that these results are consistent with Said and Grassa (2013). Other empirical evidence shows that the rule of law has a significant and positive effect on financial markets (Ojeka et al., 2019).

Regulatory Quality (RQ) is an indicator of the government's ability to formulate and to implement sound policies and regulations that permit and promote the development of the private sector. Institutional quality, by increasing capacity to implement the rule, can have a complementary relationship with Islamic financial regulations and supervision of the effects on stability. The above results appear that two of the three institutional quality indicators have a significantly positive effect on sukuk development, namely RL and GE shows a significant effect on sukuk development, while one of the three institutional quality variables does not affect sukuk development, namely RQ. From the GE results, the political stability of democraticsystem countries has a democratically-elected government and is relatively politically stable, which is committed to the development and welfare of its people. In the end, although the authorities have tried hard to support the Islamic finance industry, including in the development of sukuk instruments, government policy is still lack of optimizing these efforts. The results of this study are in line with Alam and Yazdifar (2019) that GE has a positive effect on investment development.

Institutional quality is an important indicator in developing both conventional and Islamic financial markets. Some of the previous empirical studies have provided evidence and a strong basis for the urgency of institutional quality in the development of Islamic financial markets. These results can empirically contribute to additional evidence of the previous studies on Islamic finance, especially sukuk 
applying the global-governance-indicator approach as a proxy for the role of government in the sukuk development, especially in Indonesia in which the sukuk studies are still very limited. Adibuddin et al. (2019) state that Islamic financial literacy (Islamic finance) in Indonesia, especially the capital market, only reached $14 \%$ compared to Islamic banking with $52 \%$ of the total Islamic economic research as a whole. Interestingly, none of the 184 articles analyzed in the literature has discussed WGI, the institutional quality of sukuk, or other Islamic finance.

The results of this study have some implications. Research related to institutional quality and sukuk development is still very limited. It seems that the two studies from Said and Grassa (2013) and Smaoui and Khawaja (2017) that analyze the influence of institutional quality on the development of sukuk are initial studies on this topic. Thus, this study further strengthens these two studies and provides additional empirical evidence on the relationship between institutional quality and sukuk development. In this regard, the potential for sukuk development is related to the potential for maintaining the quality of a country's institutions. Thus, these findings have implications for the future regarding the idea that the degree to which a country can strengthen its institutions, especially in terms of law enforcement and government effectiveness, will be a key determinant on sukuk development.

The results of this study are also important for investors and sukuk issuers to assess the existing investment climate adopting the WGI, when the conditions are conducive and favorable for investment and sukuk issuance for issuers. However, on top of that, the most important thing is that practitioners should be able to provide input and encouragement to the government, especially the regulators, to build a conducive Islamic-financial-investment climate considering corrections and evaluations regarding the government's role in the laws and administration of the sukuk instrument, sourced from real practice and experience. 


\section{Conclusion}

Drawing on the above-mentioned results, it can clearly be concluded that RL and GE are proven to have a significantly positive impact on the global sukuk market development; however, RQ does not. It is further revealed that the coefficient of determination (Adj. R Square) is 0.567. This finding suggests that changes in the sukuk variable (SI) by $56.7 \%$ can be explained by institutional quality variables, namely Rule of Law (RL), Regulatory Quality (RQ), and Government Effectiveness (GE), while the remaining proportion of $44,3 \%$ is explained by other factors not explained in this study. Moreover, since this study is limited to apply only three of the six-WGI indicators, further research are encouraged to test all the existing WGI dimensions or to use other indicators as a measure of the quality of government institutions, such as the International Country Risk Guide (ICRG) and Business Environmental Risk Intelligence (BERI) (Keefer, 1995). Future studies are also encouraged to test the same issue applying other methods so that the institutional-quality effect on sukuk development can be ascertained and made robust as an independent variable, or possibly as a moderating variable or a control variable.

\section{References}

Abd.Aziz, H., Idriss, U., \& Echchabi, A. (2016). Does sukuk financing promote economic growth an emphasis on the major issuing countries. Turkish Journal of Islamic Economics, 3(2), 63-63. https://doi.org/10.15238/tujise.2016.3.2.63-73

Adibuddin, A. F., Setiawan, D., \& Sutopo, B. (2019). The recent development of islamic economic studies in indonesia. Shirkah Journal of Economics and Business, 4(1), 133-173. https:// doi.org/10.22515/shirkah.v4i1.263

Ahmad, N., Daud, S. N. M., \& Kefeli, Z. (2012). Economic Forces and the sukuk market. Procedia - Social and Behavioral Sciences, 65(ICIBSoS), 127-133. https:/ / doi.org/10.1016/j.sbspro.2012.11 Alam, A., \& Yazdifar, H. (2019). Institutional determinants of R \& D investment: Evidence from emerging markets. Technological 
Forecasting $\mathcal{E} \quad$ Social Change, 138, 34-44. https://doi.org/10.1016/j.techfore.2018.08.007 Asian Development Bank. (2005). Improving the investment climate in Indonesia. In Asian Development Bank. Retrieved from https://www.adb.org/sites/default/files/publication/29709/i mproving-investment-climate-ino.pdf on September 20, 2020.

BAPPENAS. (2016). Masterplan Arsitektur Keuangan Syariah Indonesia. Retrieved from https://www.bappenas.go.id/files/publikasi_utama/Masterplan Arsitektur Keuangan Syariah Indonesia.pdf on August 18

Borhan, N. A., \& Ahmad, N. (2018). Identifying the determinants of Malaysian corporate Sukuk rating. International Journal of Islamic and Middle Eastern Finance and Management, 11(3), 432-448. https:/ / doi.org/10.1108/IMEFM-02-2017-0045

Buchanan, B. G., Le, Q. V., \& Rishi, M. (2012). Foreign direct investment and institutional quality: Some empirical evidence. International Review of Financial Analysis, 21(24), 81-89. https://doi.org/10.1016/j.irfa.2011.10.001

Challe, E., Ignacio, J., \& Mengus, E. (2019). Journal of International Money and Finance Institutional quality and capital inflows: Theory and evidence q. Journal of International Money and Finance, 96, 168-191. https:/ / doi.org/10.1016/j.jimonfin.2019.05.005

Cherif, M., \& Gazdar, K. (2010). Institutional and macroeconomic determinants of stock market development in mena region: new results from a panel data analysis. The International Journal of Banking and Finance, 7(1), 139-159.

Choi, J. J., Lee, S. M., \& Shoham, A. (2016). The effects of institutional distance on FDI inflow: General environmental institutions (GEI) versus minority investor protection institutions (MIP). International Business Review, 25(1), 114-123. https://doi.org/10.1016/j.ibusrev.2014.11.010

Ekananda, M. (2016). Analisis ekonometrika data panel: teori lengkap dan pembahasan menyeluruh bagi penelitian ekonomi, bisnis, dan sosial (Edisi kedua). Jakarta: Mitra Wacana Media.

Fagbemi, F., \& Ajibike, J. O. (2018). Institutional quality and financial sector development: empirical evidence from Nigeria. American Journal of Business and Management, 7(1), 1-13. https://doi.org/10.11634/216796061807919 
Febrina, P., \& Sumiyarni. (2014). Kelembagaan terhadap foreign direct investment di Asean 6. Media Ekonomi, 22, 241-260.

Gani, A. (2007). Governance and foreign direct investment links: Evidence from panel data estimations. Applied Economics Letters, 14(10), 753-756. https://doi.org/10.1080/13504850600592598

Globerman, S., \& Shapiro, D. (2002). Global foreign direct investment flows: The role of governance infrastructure. World Development, 30(11), 1899-1919. https://doi.org/10.1016/S0305750X(02)00110-9

Hadiah, A. N. (2016). Financial services authority (OJK) policy on debt proportion and its impact on the profitability of DES listed companies in Indonesia. Shirkah: Journal of Economics and Business, 1(3), 327. https:// doi.org/10.22515/shirkah.v1i3.29

Hassan, M. K., Aliyu, S., Paltrinieri, A., \& Khan, A. (2019). A Review of Islamic investment literature. Economic Papers, 38(4), 345-380. https://doi.org/10.1111/1759-3441.12230

Hassan, M. K., Paltrinieri, A., Dreassi, A., Miani, S., \& Sclip, A. (2018). The determinants of co-movement dynamics between sukuk and conventional bonds. Quarterly Review of Economics and Finance, 68, 73-84. https:// doi.org/10.1016/j.qref.2017.09.003

Huang, Y. (2010). Political Institutions and financial development : an empirical study. World Development, 38(12), 1667-1677. https://doi.org/10.1016/j.worlddev.2010.04.001

Intapan, C., \& Sriboonchitta, S. (2019). Structural changes and their econometric modeling. in springer nature Switzerland AG 2019 (Vol. 808). https:/ / doi.org/10.1007/978-3-030-04263-9

International Islamic Financial Market. (2014). Sukuk Report: A Comprehansive Study of the Global Sukuk Market. (November), 136. https://doi.org/10.1007/s13398-014-0173-7.2

International Islamic Financial Market. (2018). IIFM Sukuk Report 2018 |7Th Edition. (April). Retrieved from www.LABUANIBFC.com on September 15, 2020.

Jain, P. K., Kuvvet, E., \& Pagano, M. S. (2017). Corruption's impact on foreign portfolio investment. International Business Review, 26(1), 23-35. https:// doi.org/10.1016/j.ibusrev.2016.05.004

Kaufmann, D., Kraay, A., \& Mastruzzi, M. (2005). Governance Matters IV: Governance Indicators for 1996-2004. SSRN Electronic Journal. https://doi.org/10.2139/ssrn.718081 
Kaufmann, D., Kraay, A., \& Mastruzzi, M. (2009). Governance matters VII: Aggregate and individual governance indicators 1996-2007. Non-State Actors as Standard Setters, (June), 146-188. https://doi.org/10.1017/CBO9780511635519.007

Kaufmann, D., Kraay, A., \& Mastruzzi, M. (2011). Governance matters vii: aggregate and individual governance indicators, 1996-2007. SSRN Electronic Journal, (June). https://doi.org/10.2139/ssrn.1148386

Keefer, S. K. and P. (1995). Institutions and economic performance: cross-country tests using alternative institutional measures. Economic and Politics, 7(3), 207-227. https:// doi.org/10.1111/j.1468-0343.1995.tb00111.x

Khan, M. A., Khan, M. A., Abdulahi, M. E., Liaqat, I., \& Shah, S. S. H. (2019). Institutional quality and financial development: The United States perspective. Journal of Multinational Financial Management, 49, 67-80. https://doi.org/10.1016/j.mulfin.2019.01.001

Kusuma, K. A., \& Silva, A. C. (2014). Sukuk Markets A Proposed Approach for Development. Policy Research Working Paper Series, (December), 41. https://doi.org/10.1596/1813-9450-7133

Langbein, L., \& Knack, S. (2012). The Worldwide Governance Indicators : Six , One, or None? The Journal of Development Studies, 46, No 2(November 2012), 350-370. https://doi.org/10.1080/00220380902952399

Law, S. H., \& Azman-Saini, W. N. W. (2012). Institutional quality, governance, and financial development. Economics of Governance, 13(3), 217-236. https:/ / doi.org/10.1007/s10101-012-0112-z

Ojeka, S., Adegboye, A., Adegboye, K., Umukoro, O., Dahunsi, O., \& Ozordi, E. (2019). Corruption perception, institutional quality and performance of listed companies in Nigeria. Heliyon, 5(10), e02569. https:/ / doi.org/10.1016/j.heliyon.2019.e02569

Paltrinieri, A., Dreassi, A., Migliavacca, M., \& Piserà, S. (2020). Islamic finance development and banking ESG scores: Evidence from a cross-country analysis. Research in International Business and Finance, 51, 1-13. https://doi.org/10.1016/j.ribaf.2019.101100

Phuc, N., Schinckus, C., Dinh, S., Phuc Canh, N., Schinckus, C., \& Thanh, S. D. (2019). Do economic openness and institutional quality influence patents? Evidence from GMM systems 
estimates. International Economics, 157(October), 134-169. https:// doi.org/10.1016/j.inteco.2018.10.002

Robinson, J. (1952). The Model of an Expanding Economy. The Economic Journal, 62(245), 42-53. http://www.jstor.org/stable/2227172

Roodman, D. (2009). How to do xtabond2: An introduction to difference and system GMM in Stata. Stata Journal, 9(1), 86-136. https:// doi.org/10.1177/1536867x0900900106

Roe, M. J., \& Siegel, J. I. (2011). Political instability: Effects on financial development, roots in the severity of economic inequality. Journal of Comparative Economics, 39(3), 279-309. https://doi.org/10.1016/j.jce.2011.02.001

Said, A., \& Grassa, R. (2013). The determinants of sukuk market development: Does macroeconomic factors influence the construction of certain structure of sukuk? Journal of Applied Finance $\mathcal{E}$ Banking, 3(5), 251-267. Retrieved from https:/ / ssrn.com/abstract=2318233 on September 15, 2020.

Smaoui, H., \& Ghouma, H. (2020). Sukuk market development and Islamic banks' capital ratios. Research in International Business and Finance, 51(17). https:/ / doi.org/10.1016/j.ribaf.2019.101064

Smaoui, H., \& Khawaja, M. (2017). The Determinants of sukuk market development. Emerging Markets Finance and Trade, 53(7), 15011518. https:/ / doi.org/10.1080/1540496X.2016.1224175

Tran, H. T. (2018). Institutional quality and market selection in the transition to market economy. Journal of Business Venturing, 1-27. https:// doi.org/10.1016/j.jbusvent.2018.07.001

Wang, Y., Cheng, L., Wang, H., \& Li, L. (2014). Institutional quality, financial development and OFDI. Pacific Science Review, 16(2), 127-132. https:/ / doi.org/10.1016/j.pscr.2014.08.023

Widarjono, A. (2007). Ekonometrika Pengantar dan Aplikasinya (Edisi Kedua). Yogyakarta: Ekonisia.

Yustika, A. E. (2012). Ekonomi Kelembagaan: Paradigma, Teori, dan Kebijakan. Malang: Erlangga. 